\title{
The Studying of Relationship Spiritual Intelligence and Communicational Skills of Central Organization Managers in Azad University
}

\author{
Iman Mahdi Raki \\ M.A. in Mass communication at Department of Communication Sciences, \\ College of Social Sciences, East Tehran Branch, Islamic Azad University, Tehran, Iran \\ Mandana Saniee, Ph.D \\ Corresponding Author, Assistant Professor in Mass Communication at Department of Communication Sciences, \\ College of Social Sciences, East Tehran Branch, Islamic Azad University, Tehran, Iran \\ Email: mandanasaniee@yahoo.com

\section{Seddiqeh Tootian Esfahani, Ph.D}

Assistant Professor, College of Social Sciences, East Tehran Branch, Islamic Azad University, Tehran, Iran

Doi:10.5901/mjss.2016.v7n3s3p273

\section{Abstract}

\begin{abstract}
The goal of research understood of relationship between spiritual intelligence and communicational skills of central organization managers in Islamic Azad University. Statistical society including 85 persons of both men and women managers in central organization of Islamic Azad university who work in 2014. That by using of Morgan sample volume evaluating table, 70 persons chosen randomly. Research method was in survey way and used standard questionnaire of King spiritual intelligence and communicational skills to collect required information. Collected information were analyzed using of statistical application SPSS with descriptive and inferential statistical methods. Research findings using of Pearson correlation coefficient test and multiple linear regressions showing that there are relationship between quadruple abilities of King spiritual intelligence and communicational skills of managers. Also there are relationship between existential critical thoughts skill, making personal meaning, lofty awareness and developing consciousness situation with communicational skills of managers.
\end{abstract}

Keywords: communicational skills, spiritual intelligence, existential critical thoughts, making personal meaning, lofty awareness.

\section{Introduction}

The importance and necessity of spirituality subject specially spiritual intelligence feels in different aspects in modern era and different organizations, including, advent of spiritual attraction and also looking for better understanding of faith and its using in solving problems and making decisions, spiritual intelligence required abilities that used spirituality subjects for adapting and effective attraction and manufacturing products and worthy consequences (Sohrabi, 1999).

Also It is said that, spiritual intelligence facilitate understanding of religious issues and appropriate Feqh inferences and help people in understanding of moral issues and its value (Ghobari benab et al, 2007:22)

Some of the communication experts have represented complete definition for communication: "communication is transmission of message from sender to recipient, if in recipient made meaning hyponym with sender meaning of message. Communication is a process that is a dynamic and continuous activity that is continuously changing. In communication process, made meaning transmission. It should be adapted received meaning with sender meaning in communication process so that, made idea communication between them. Communication is considered part of human social life and without it social life is impossible. Developing and evolving of communicational activities and society understanding from its key role for making radical changes is so deep and fast that it is considered a primary area for every social and cultural change in developing of communicational networks. modern word used advanced technology in communications and is increasingly added to its complexity and usage range so that, most of developing countries for making radical changes, try to use communication technology, modern life, after meeting primary needs, for developing and evolving inevitably used communicational networks and also developing and evolving of social communications. In fact without thinking and developing of communication in all of its aspects, society is depressed and such a society 
considered a dead society.

In this research, a researcher try to investigating and studying relationship between spiritual intelligence and communicational skills of managers, and based on presented analytical model, this subject has considered in central organization of Azad university.

\section{Research Hypothesis}

\subsection{Primary hypothesis}

There are relationship between quadruple abilities of king spiritual intelligence and communicational skills of managers in Islamic Azad university.

Secondary hypotheses there are relationship between existential critical thought and communicational skills of managers in Islamic Azad University. University.

There are relationship between personal meaning and communicational skills of managers in Islamic Azad University.

There are relationship between lofty awareness and communicational skills of managers in Islamic Azad

There are relationship between developing of consciousness situation and communicational skills of managers in Islamic Azad University.

\section{Statistical Society}

Statistical society including all of the men and women managers of central organization in Islamic Azad University who work in 2014. Based on registered statistics in employment office of central organization in Azad university 85 managers work in this area.

\section{Determining of Sample Volume and Sampling Method}

Based on volume of 85 managers society and referring to Morgan sample volume evaluating table, it is considered 70 mangers for responding to questionnaire of spiritual intelligences and communicational skills questionnaire for choosing samples used random sampling method. Based on the numbers of mangers in Azad university were available in gender grouping so, 70 required samples based on gender rate from society are chosen, so that 11 women and 59 men managers chosen as research samples in following table listed number of managers in gender separation.

Table 1: number of research samples in gender separation

\begin{tabular}{|c|c|c|c|}
\hline Gender & Total number of manager & Percent out of all society & Sample number base on population \\
\hline Women & 14 & 16.4 & 11 \\
\hline Men & 71 & 83.6 & 59 \\
\hline Total & 85 & 100 & 70 \\
\hline
\end{tabular}

\section{Research Tools}

To collect required information with referring to library sources and available documents. Some of the required information is derived, other tools used in this research was standard questionnaire spiritual intelligence and communicational skills questionnaire. Spiritual intelligence questionnaire associated with king.

This questionnaire was developed by king in 2008. Spiritual intelligence questionnaire include 20 questions of quintuple choices that tested answer to his or her question from $1-5$ score. Highest score showing highest level of spiritual intelligence.

This questionnaire including four sub scales:

1- Critical existential thought

2- Making personal meaning

3- Developing of conscious experience

4- Increasingly consciousness. 
Communicational skills questionnaire include 18 questions of quintuple choices which invented by AL, Bartoon G. This questionnaire included 3 sub scales:

1- Verbal skills

2- Audio skills

3- Feedback skills

\section{Analyzing Method of Data}

To analyzing, classifying, summarizing, description and interpreting and making communication by collected information to respond to test of research hypotheses used statistical descriptive and inferential methods, it is used descriptive statistic for deriving frequencies and responding percent to choices and comparing and understanding of findings values. Inferential level used kologroph-Sminroph test for recognizing of normal data and in test of research questions used Pearson correlation coefficient test and multiple linear regression test.

\section{Inferential Analyzing of Data}

Primary hypothesis: there are relationship between quadruple abilities of king spiritual intelligence and managers communicational skills of central organization in Azad university

To study above hypothesis of multiple linear regression test used following tables:

Table 3: summary of statistical indexes

\begin{tabular}{|l|c|c|c|c|}
\hline \multirow{2}{*}{ model } & \multicolumn{4}{|c|}{ Statistical indexes } \\
\cline { 2 - 5 } & $\begin{array}{c}\text { Multiple correlation } \\
\text { coefficient } ®\end{array}$ & $\begin{array}{c}\text { Multiple explaining } \\
\text { coefficient }\left(\mathrm{R}^{2}\right)\end{array}$ & $\begin{array}{c}\text { Balanced multiple } \\
\text { explaining coefficient }\end{array}$ & $\begin{array}{c}\text { Standard deviation of multiple } \\
\text { explaining coefficient }\end{array}$ \\
\hline $\begin{array}{l}\text { Quadruple dimensions of } \\
\text { spiritual intelligence }\end{array}$ & 0.337 & 0.114 & 0.059 & 0.626 \\
\hline
\end{tabular}

Based on above data and measured $\mathrm{R}$ value. It can stated that there are relationship between multiple abilities of king spiritual intelligence (critical existential thought, making personal meaning, lofty awareness and developing of consciousness situation) and managers communicational skills about 0.337 . also by observing measured $\mathrm{R}^{2}$ value for variants it is concluded that in view of managers of central organization, multiple abilities of king spiritual intelligence explain \%11 changes of managers communicational skills.

Table 4: one way variance analyze

\begin{tabular}{|c|c|c|c|c|c|}
\hline model & Total Squares & Freedom degree & Squares average & $\mathrm{F}$ & Significant level \\
\hline regression & 3.278 & 4 & 0.819 & 2.085 & 0.045 \\
\hline Subtract & 25.541 & 65 & 0.393 & & \\
\hline Total & 28.819 & 69 & & & \\
\hline
\end{tabular}

Based on above data and significant level of test $(p=0.045)$ and $(p<0.05)$ it can stated that in view of managers in Azad university, there are significant relationship between multiple abilities of king spiritual intelligence and managers communicational skills and at least one of the coefficients is significant so, analyzing of regression equation is provided.

Table 5: coefficients associated with primary hypothesis

\begin{tabular}{|l|c|c|c|c|c|}
\hline \multirow{2}{*}{ Model } & \multicolumn{2}{|c|}{ Non-standard coefficient } & Standard coefficient & \multirow{2}{*}{$\mathrm{t}$} & \multirow{2}{*}{ Significant level } \\
\cline { 2 - 5 } & $\mathrm{B}$ & Error of standard deviation & $\beta$ & & \\
\hline Constant & 4.402 & 0.628 & & 7.006 & 0.000 \\
\hline Critical existential thought & 0.720 & 0.274 & 0.586 & 4.630 & 0.000 \\
\hline Making personal meaning & 0.336 & 0.207 & 0.390 & 3.625 & 0.000 \\
\hline Lofty awareness & 0.058 & 0.195 & 0.066 & 2.268 & 0.109 \\
\hline Developing of awareness situation & 0.263 & 0.196 & 0.238 & 3.352 & 0.025 \\
\hline
\end{tabular}


Based on above data and value of $\beta$ coefficient for inserted variants to regression, it seen that critical existential thought (0.586), making personal meaning (0.390), lofty awareness (0.066) and developing of consciousness situation (0.238) have relationship with managers communicational skills, on the other hand, based on less significant level test from $(p<0.05)$ in 3 dimensions of critical existential thought, making personal meaning, lofty awareness, and developing of consciousness situation it can be concluded that, above relationship are significant. On the other word, it can be stated that, in view of Azad university managers there are significant relationship between quadruple abilities of king spiritual intelligence and communicational skills, so research hypothesis is verified and zero hypothesis rejected. Based on $\beta$ coefficient value of critical existential thought, it can be concluded that this dimension has the most contribution in explaining of managers communicational skills.

First secondary hypothesis: there are relationships between existential critical thought and managers communicational skills of central organization in Azad University. For studying of above hypothesis used Pearson correlation coefficient test as following.

Table 6: Pearson correlation coefficient test

\begin{tabular}{|l|l|c|c|}
\hline \multicolumn{2}{|c|}{} & Existential critical thought & Communicational skills \\
\hline \multirow{3}{*}{ Existential critical thought } & Correlation & 1 & 0.351 \\
\cline { 2 - 4 } & Significant level & & 0.000 \\
\cline { 2 - 4 } & Number & 70 & 70 \\
\hline \multirow{3}{*}{ Communicational skills } & Correlation & 0.351 & 1 \\
\cline { 2 - 4 } & Significant level & 0.000 & 70 \\
\cline { 2 - 4 } & Number & 70 & 70 \\
\hline
\end{tabular}

Based on above data it seen that, existential critical thought about $r=0.351$ has relationship with managers communicational skills. On the other hand, based on less significant level of test from $(p<0.05)$ it can be stated that above relationship is significant, so, research hypothesis accepted and zero hypothesis rejected. On the other word, it can be concluded that in view of managers there are relationship between existential critical thought and managers communicational skills of central organization in Azad University.

Second secondary hypothesis: there are relationship between making of personal meaning and managers communicational skills of central organization in Azad University. For studying of above hypothesis used Pearson correlation coefficient test as following.

Table 7: Pearson correlation coefficient test

\begin{tabular}{|l|l|c|c|}
\hline \multicolumn{2}{|c|}{} & Making personal meaning & Communicational skills \\
\hline \multirow{3}{*}{ Making personal meaning } & Correlation & 1 & 0.296 \\
\cline { 2 - 4 } & Significant level & & 0.000 \\
\cline { 2 - 4 } & Number & 70 & 70 \\
\hline \multirow{3}{*}{ Communicational skills } & Correlation & 0.296 & 1 \\
\cline { 2 - 4 } & Significant level & 0.000 & 70 \\
\cline { 2 - 4 } & Number & 70 & \\
\hline
\end{tabular}

Based on above data it seen that, making personal meaning about $r=0.296$ has relationship with managers communicational skills. On the other hand, based on less significant level of test from $(p<0.05)$ it can be stated that above relationship is significant, so, research hypothesis is accepted and zero hypothesis rejected. On the other word, it can be concluded that in view of managers there are relationship between making personal meaning and managers communicational skills of central organization in Azad University.

Third secondary hypothesis: there is relationship between lofty awareness and managers communicational skills of central organization in Azad University.

For studying of above hypothesis used Pearson correlation coefficient test as following 
Table 8: Pearson correlation coefficient test

\begin{tabular}{|l|l|c|c|}
\hline \multicolumn{2}{|c|}{} & Lofty awareness & Communicational skills \\
\hline \multirow{3}{*}{ Existential critical thought } & Correlation & 1 & 0.187 \\
\cline { 2 - 4 } & Significant level & & 0.039 \\
\cline { 2 - 4 } & Number & 70 & 70 \\
\hline \multirow{3}{*}{ Communicational skills } & Correlation & 0.187 & 1 \\
\cline { 2 - 4 } & Significant level & 0.039 & 70 \\
\cline { 2 - 4 } & Number & 70 & 70 \\
\hline
\end{tabular}

Based on above data it seen that, lofty awareness about $r=0.187$ has relationship with managers communicational skills. On the other hand, based on less significant level of test from $(p<0.05)$ it can be stated that above relationship is significant, so, research hypothesis is accepted and zero hypothesis rejected. On the other word, it can be concluded that in view of managers there are relationship between lofty awareness and managers communicational skills of central organization in Azad University.

Fourth secondary hypothesis: there are relationships between developing of consciousness situation and managers communicational skills of central organization in Azad University.

For studying of above hypothesis used Pearson correlation coefficient test as following.

Table 9: Pearson correlation coefficient test

\begin{tabular}{|l|l|c|c|}
\hline \multicolumn{2}{|c|}{} & Developing of consciousness situation & Communicational skills \\
\hline \multirow{3}{*}{ Existential critical thought } & Correlation & 1 & 0.204 \\
\cline { 2 - 4 } & Significant level & & 0.025 \\
\cline { 2 - 4 } & Number & 70 & 70 \\
\hline \multirow{3}{*}{ Communicational skills } & Correlation & 0.204 & 1 \\
\cline { 2 - 4 } & Significant level & 0.025 & 70 \\
\cline { 2 - 4 } & Number & 70 & \\
\hline
\end{tabular}

Based on above data it seen that, developing of consciousness situation about $r=0.204$ has relationship with managers communicational skills. On the other hand, based on less significant level of test from $(p<0.05)$ it can be stated that above relationship is significant, so, research hypothesis is accepted and zero hypothesis rejected. On the other word, it can be concluded that in view of managers there are relationship between developing of awareness situation and managers communicational skills of central organization in Azad University.

\section{Conclusion}

the noticeable effect of spiritual intelligence on important management variants including, leadership, instigation, selfcontrolling, changing capacity, communication, performance, and its relationship with other kinds of intelligence led to that spirituality and spiritual intelligence change in to the important subject in management and organization range. Managers who having spiritual view are more flexible rather than other managers and looking for goal and meaning for organization. And they understand the importance of connecting to bigger organization, having perception and personal statement from own spirituality, these kind of people are open minded that is they believed that there is enough sources for all of people and don't need for competition. As a result people can trust in each other easily, and shared their information and work .and adaptable to their colleagues and members of group till they reach to their goals. people in organizations hierarchy which having spiritual tendency, try for developing of each other, and in conflict situations use win - win contributions strategies.

Today, psychologist believe that ultimate success of a big organization depended on spiritual intelligence of managers, although, intellectual intelligence and emotional intelligence guarantee success fullness. they believe spiritual encouragement in work place led to increasing creativity, truthfulness and self-confidence of personal evolving, organizational fulfillment, job satisfying, job contributing, temperament, conscientious, motivation, high performance. A spiritual manager is able to manage an organization so that all of the consumers, employees and people can benefit it. 


\section{References}

Rjayy, A. (1389), "Spiritual Intelligence: Perspectives and Challenges", Journal of Educational Branch Torbatejam, No. 22. Sohrabi, F., (1387), "Principles of Spiritual Intelligence", Mental Health, Vol I, Issue I,

Zohar , D. \& Marshal, I. (2000). SQ - Spiritual in T cell Igence, the ultimate intelligence. London: BLOOMBURY.

\section{Internet References}

http://www.Itmanagement. Com/post- 384Aspx

http://www. Irandoc.ac.ir/ETEJA-ICT/18/18

http://www. Iranwsis.org/Education. asp?c=IRAR\&R=81-202

http://www. Daricheh.org/dakheli.php?news-id=32

http://www. Itmanagement .mihanblog.com/post-6aspx

http://www. Artuoshmanager.bolgfa.com/84064.asps

http://www.Kmterms mihanblog.com/page-5aspx

http://www.imi.ir/tadbir/tadbir-169/article-169/4asp 